Supporting Information

\title{
Discrete Metal-Oxide Clusters with Organofunctionalization as High- Performance Anode Materials
}

Tushar Sanjay Jadhav, ${ }^{\dagger}, \&, \#$ Syed Ali Abbas,,$\#$ Yu-Chiao Liu, ${ }^{\dagger}$ Wen-Ti Wu,${ }^{\dagger}$ Gene-Hsiang Lee, ${ }^{\diamond}$

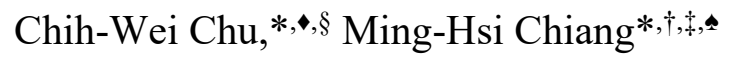

${ }^{\dagger}$ Institute of Chemistry, Academia Sinica, Nankang, Taipei 115, Taiwan

$\ddagger$ Sustainable Chemical Science and Technology, Taiwan International Graduate Program, Academia Sinica, Nankang, Taipei 115, Taiwan

$\S$ Department of Applied Chemistry, National Chiao Tung University, Hsinchu 300, Taiwan

- Research Center for Applied Sciences, Academia Sinica, Nankang, Taipei 115, Taiwan

$\checkmark$ Department of Chemistry and Instrumental Center, National Taiwan University, Taipei, 106 Taiwan

- Department of Medicinal and Applied Chemistry, Kaohsiung Medical University, Kaohsiung 807 , Taiwan

\# Tushar Jadhav and Syed Ali Abbas equally contributed to this work

*To whom correspondence should be addressed: mhchiang@chem.sinica.edu.tw 


\section{Contents}

\section{Crystallographic results of 1-3}

Table S1. X-ray crystallographic data.

Table S2. Selected bond distances $(\AA)$ and angles $\left(^{\circ}\right)$ of 1-3.

\section{Characterization}

Figure S1. Molecular structure of 2.

Figure S2. UV-vis spectra of $\mathbf{1}$ and $\mathbf{2}$ in $\mathrm{MeCN}$ solution.

Figure S3. FTIR spectra of 1-3 in $\mathrm{KBr}$ pellets.

Figure S4. TGA plots of 1-3 and $[\mathrm{TBA}]_{2}\left[\mathrm{Mo}_{6} \mathrm{O}_{19}\right]$.

Figure S5. $\mathrm{N}_{2}$ adsorption-desorption isotherms of $\mathrm{CB}$, electrode materials fabricated with of 3 and $[\mathrm{TBA}]_{2}\left[\mathrm{Mo}_{6} \mathrm{O}_{19}\right]$.

\section{Electrochemical performance}

Table S3. A list of selected high-capacity anode materials fabricated with discrete POMs, POM composite or $\mathrm{Mo}_{\mathrm{x}} \mathrm{O}_{\mathrm{y}}$ bulk materials for the application of lithium ion batteries.

Table S4. Simulated Warburg factor $(\sigma)$ and calculated lithium-ion diffusivity parameter $\left(D_{\mathrm{Li}+}\right)$ for 3 and $\left[\mathrm{TBA}_{2}\left[\mathrm{Mo}_{6} \mathrm{O}_{19}\right]\right.$.

Figure S6. The $1^{\text {st }}$ and $2^{\text {nd }}$ charge-discharge cycle of $\mathbf{1}, \mathbf{2}$ and $[\mathrm{TBA}]_{2}\left[\mathrm{Mo}_{6} \mathrm{O}_{19}\right]$.

Figure S7. Cycle performance of $\mathbf{3}$ at $0.134 \mathrm{C}$.

Figure S8. Cycle performance of 3 at $1.2 \mathrm{C}$.

Figure S9. Cycle performance of 3 in a weight ratio of 70:20:10 (AM:CB:PVDF binder) and 50:40:10 at $1.20 \mathrm{C}$.

Figure S10. Cycle performance of $[\mathrm{TBA}]_{2}\left[\mathrm{Mo}_{6} \mathrm{O}_{19}\right]$ at $1.2 \mathrm{C}$.

Figure S11. The EDX analysis of the F-electrode and the top coating layer of the $\mathbf{C}$ electrode.

Figure S12. The TEM images of carbon black and POM 3.

Figure S13. The TEM images of the electrode materials of $[\mathrm{TBA}]_{2}\left[\mathrm{Mo}_{6} \mathrm{O}_{19}\right]$ in the various states. The SEM images of the electrode materials of $[\mathrm{TBA}]_{2}\left[\mathrm{Mo}_{6} \mathrm{O}_{19}\right]$ in the various states.

Figure S14. The EDX analysis of the electrode materials of $[\mathrm{TBA}]_{2}\left[\mathrm{Mo}_{6} \mathrm{O}_{19}\right]$ and the top coating layer of the electrode materials of $[\mathrm{TBA}]_{2}\left[\mathrm{Mo}_{6} \mathrm{O}_{19}\right]$.

Figure S15. Comparison of FTIR spectra of RN-POM 3, the fresh EM_3 and the cycled EM_3 in KBr pellets.

Figure S16. The linear relationship between $Z^{\prime}$ and $\omega^{-1 / 2}$ of $\mathbf{3}$ and $[\mathrm{TBA}]_{2}\left[\mathrm{Mo}_{6} \mathrm{O}_{19}\right]$ at the various states at the low frequency region. 


\section{Crystallographic results of 1-3}

Table S1. X-ray crystallographic data.

\begin{tabular}{|c|c|c|c|}
\hline & $\mathbf{1} \cdot 2 \mathrm{EtOH}$ & $2 \cdot \mathrm{CH}_{3} \mathrm{C}(\mathrm{O}) \mathrm{CH}_{3}$ & $\mathbf{3} \cdot 2 \mathrm{EtOH}$ \\
\hline Empirical formula & $\mathrm{C}_{53} \mathrm{H}_{108} \mathrm{Cl}_{2} \mathrm{Mo}_{6} \mathrm{~N}_{6} \mathrm{O}_{18}$ & $\mathrm{C}_{52} \mathrm{H}_{104} \mathrm{Mo}_{6} \mathrm{~N}_{6} \mathrm{O}_{17}$ & $\mathrm{C}_{55} \mathrm{H}_{114} \mathrm{Mo}_{6} \mathrm{~N}_{6} \mathrm{O}_{18}$ \\
\hline Formula weight & 1763.99 & 1661.05 & 1723.16 \\
\hline$T, \mathrm{~K}$ & $150(2)$ & $150(2)$ & $150(2)$ \\
\hline Crystal system & Monoclinic & Monoclinic & Monoclinic \\
\hline Space group & $\mathrm{P} 2{ }_{1} / \mathrm{c}$ & $\mathrm{P} 21 / \mathrm{n}$ & $\mathrm{P} 2{ }_{1} / \mathrm{c}$ \\
\hline$a, \AA$ & $24.059(3)$ & $15.8817(6)$ & $24.1110(7)$ \\
\hline$b, \AA$ & $12.8296(17)$ & $15.9151(6)$ & $12.8318(4)$ \\
\hline$c, \AA$ & $24.480(3)$ & $26.7612(10)$ & $24.5150(7)$ \\
\hline$\alpha,^{\circ}$ & 90 & 90 & 90 \\
\hline$\beta,^{\circ}$ & $112.942(2)$ & $102.1767(7)$ & $112.7883(7)$ \\
\hline$\gamma,{ }^{\circ}$ & 90 & 90 & 90 \\
\hline$V, \AA^{3}$ & $6958.5(16)$ & $6611.9(4)$ & $6992.6(4)$ \\
\hline Z & 4 & 4 & 4 \\
\hline$\rho_{\text {calcd, }} \mathrm{Mg} \mathrm{m}^{-3}$ & 1.684 & 1.669 & 1.637 \\
\hline$\mu, \mathrm{mm}^{-1}$ & 1.192 & 1.170 & 1.110 \\
\hline$F(000)$ & 3592 & 3384 & 3528 \\
\hline Reflections collected & 47990 & 64163 & 72961 \\
\hline Independent reflections & 15948 & 19265 & 20373 \\
\hline$R_{\text {int }}$ & 0.0539 & 0.0410 & 0.0560 \\
\hline Goodness-of-fit on $\mathrm{F}^{2}$ & 1.094 & 1.071 & 1.070 \\
\hline $\mathrm{R} 1[I>2 \sigma(I)](\text { all data })^{\mathrm{a}}$ & $0.0499(0.0713)$ & $0.0314(0.0470)$ & $0.0362(0.0563)$ \\
\hline $\mathrm{wR} 2[I>2 \sigma(I)](\text { all data })^{\mathrm{b}}$ & $0.1251(0.1442)$ & $0.0619(0.0699)$ & $0.0734(0.0845)$ \\
\hline
\end{tabular}

${ }^{\mathrm{a}} \mathrm{R} 1=\left(\Sigma|| F_{\mathrm{o}}|-| F_{\mathrm{c}} \mid\right) /\left(\sum\left|F_{\mathrm{o}}\right|\right),{ }^{\mathrm{b}} \mathrm{wR} 2=\left[\sum w\left(F_{\mathrm{o}}{ }^{2}-F_{\mathrm{c}}{ }^{2}\right)^{2} / \sum w\left(F_{\mathrm{o}}{ }^{2}\right)^{2}\right]^{1 / 2}$. 
Table S2. Selected bond distances $(\AA)$ and angles $\left(^{\circ}\right)$ of 1-3.

\begin{tabular}{llll}
\hline \hline & \multicolumn{1}{c}{1} & \multicolumn{1}{c}{$\mathbf{2}$} & \multicolumn{1}{c}{3} \\
\hline $\mathrm{Mo}^{\mathrm{N}}-\mathrm{N}_{\mathrm{t}}$ & ave.1.719(5) & ave. 1.724(2) & ave. 1.717(3) \\
$\mathrm{Mo}^{\mathrm{N}}-\mathrm{N}_{\mathrm{b}}$ & ave. $2.017(4)$ & ave. 2.0181(20) & ave. 2.016(2) \\
$\mathrm{Mo}^{\mathrm{N}}-\mathrm{O}_{\mathrm{c}}$ & ave. $2.220(3)$ & ave. 2.2166(15) & ave. 2.2116(19) \\
$\mathrm{Mo}-\mathrm{O}_{\mathrm{t}}$ & ave. 1.689(4) & ave. 1.6896(18) & ave. 1.691(2) \\
$\mathrm{Mo}-\mathrm{O}_{\mathrm{c}}$ & ave. 2.377(3) & ave. 2.3808(16) & ave. 2.3812(19) \\
$\mathrm{Mo}^{\mathrm{N}}-\mathrm{N}-\mathrm{C}$ & ave. 167.1(5) & ave. 169.31(24) & ave. 167.8(3) \\
$\mathrm{Mo}^{\mathrm{N}} \mathrm{N}_{\mathrm{b}}-\mathrm{Mo}^{\mathrm{N}}$ & $107.19(19)$ & $107.79(9)$ & $106.84(11)$ \\
\hline \hline
\end{tabular}


Table S3. A list of selected high-capacity anode materials fabricated with discrete POMs, POM composite or $\mathrm{Mo}_{\mathrm{x}} \mathrm{O}_{\mathrm{y}}$ bulk materials for the application of lithium ion batteries.

\begin{tabular}{|c|c|c|c|c|}
\hline Material & $\begin{array}{l}\text { Current Density } \\
\qquad\left(\mathrm{mA} \mathrm{g}^{-1}\right)\end{array}$ & $\begin{array}{c}\text { Capacity } \\
\left(\mathrm{mAh} \mathrm{g}^{-1}\right) / \text { cycles }\end{array}$ & $\begin{array}{l}\text { AM Used } \\
\quad(\%)\end{array}$ & Ref \\
\hline \multicolumn{5}{|c|}{ Discrete POMs } \\
\hline & $100\left(0.134^{b}\right)$ & $1910 / 450$ & 50 & \\
\hline RN-POM 3 & $800\left(1.07^{b}\right)$ & $1275 / 550$ & 50 & This work \\
\hline & $900\left(1.20^{\mathrm{b}}\right)$ & $840 / 500$ & 70 & \\
\hline $\mathrm{Mo}_{6} \mathrm{O}_{18}-\mathrm{SCN}$ & 50 & $876 / 100$ & 40 & 1 \\
\hline \multicolumn{5}{|c|}{ POM composite } \\
\hline HP-NENU-5/CC & 200 & $1723 / 100$ & 100 & 2 \\
\hline$\left[\mathrm{CoMo}_{8} \mathrm{O}_{26}\right]_{\infty}$ & 100 & $1083 / 100$ & 60 & 3 \\
\hline PMG-3 & 50 & $1075 / 100$ & 70 & 4 \\
\hline MIL-88A@PMo12 & 200 & $1062 / 100$ & 70 & 5 \\
\hline $\begin{array}{c}{\left[\mathrm{PMo}_{8}{ }^{\mathrm{V}} \mathrm{Mo}_{4}{ }^{\mathrm{VI}} \mathrm{O}_{37}(\mathrm{OH})_{3} \mathrm{Zn}_{4}\right][\mathrm{BPP}]_{2} \bullet} \\
2\left[\text { pyridine } \bullet \bullet 2 \mathrm{H}_{2} \mathrm{O}\right.\end{array}$ & 100 & $1004 / 100$ & 70 & 6 \\
\hline $\mathrm{PMo}_{12} / \mathrm{PANI} / \mathrm{MWNTs}$ & $0.5^{\mathrm{a}}$ & $1000 / 100$ & 80 & 7 \\
\hline$\left[\mathrm{AlMo}_{6} \mathrm{O}_{24} \mathrm{H}_{6}\right]^{3-}$-EDAG & 100 & $1000 / 100$ & 80 & 8 \\
\hline $\mathrm{PMo}_{12} / 3 \mathrm{D}$ Carbon & 1000 & $985 / 200$ & 80 & 9 \\
\hline $\begin{array}{c}{\left[\mathrm{MnMo}_{6} \mathrm{O}_{18}\left\{\left(\mathrm{OCH}_{2}\right)_{3} \mathrm{CNH}_{2}\right\}_{2}\right]-} \\
\mathrm{SWNT}\end{array}$ & $0.5^{\mathrm{a}}$ & $932 / 100$ & 50 & 10 \\
\hline $\mathrm{PMo}_{10} \mathrm{~V}_{2} / \mathrm{PDA}$ & 100 & $915 / 65$ & 80 & 11 \\
\hline TBA-PMo ${ }_{11} \mathrm{~V} / \mathrm{CNTs}$ & $0.5^{\mathrm{a}}$ & $850 / 100$ & 80 & 12 \\
\hline 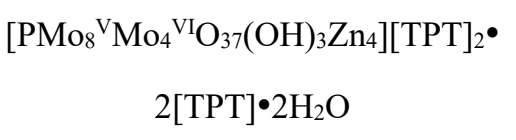 & 50 & $750 / 200$ & 70 & 13 \\
\hline \multicolumn{5}{|c|}{ Mo $_{\mathrm{x}} \mathrm{O}_{\mathrm{y}}$ bulk materials } \\
\hline mesoporous $\mathrm{MoO}_{2}$ & $0.1^{\mathrm{b}}$ & $1607 / 50$ & 70 & 14 \\
\hline $\mathrm{MoO}_{2} / \mathrm{MWCNTs}$ & 100 & $1143 / 200$ & 80 & 15 \\
\hline $\mathrm{MoO}_{2} /$ graphene & 100 & $1010 / 60$ & 80 & 16 \\
\hline $\mathrm{MoO}_{2} / 3 \mathrm{D}$ graphene & 200 & $987 / 150$ & 70 & 17 \\
\hline $\mathrm{MoO}_{3} / \mathrm{rGO}$ & $0.1^{\mathrm{b}}$ & $984 / 100$ & 80 & 18 \\
\hline Hierarchical $\mathrm{MoO}_{2}-\mathrm{C}$ spheres & 200 & $812 / 150$ & 80 & 19 \\
\hline $\mathrm{MoO}_{3} \mathrm{NP}^{\mathrm{c}}$ & $0.1^{\mathrm{b}}$ & $382 / 100$ & 80 & 18 \\
\hline
\end{tabular}

${ }^{\mathrm{a}} \mathrm{mA} \mathrm{cm}{ }^{-1} \cdot{ }^{\mathrm{b}} \mathrm{C}$-rate. ${ }^{\mathrm{c}}$ for comparison. 


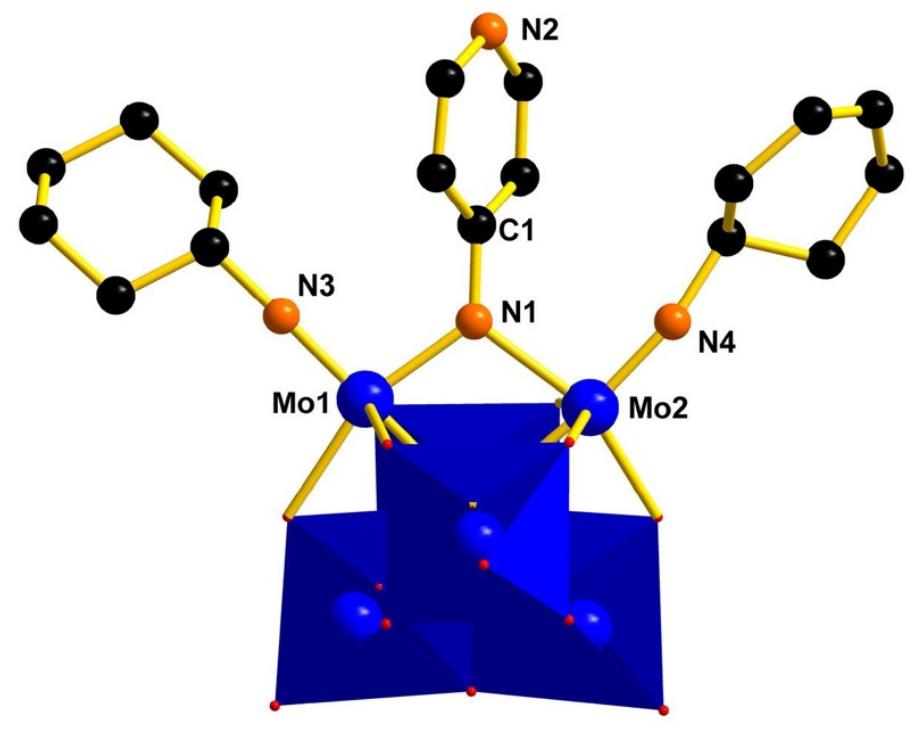

Figure S1. Molecular structure of 2. All hydrogen atoms are omitted for clarity. The complex is displayed as a polyhedral presentation except for the organo-imido groups and the corresponding ligated Mo sites.
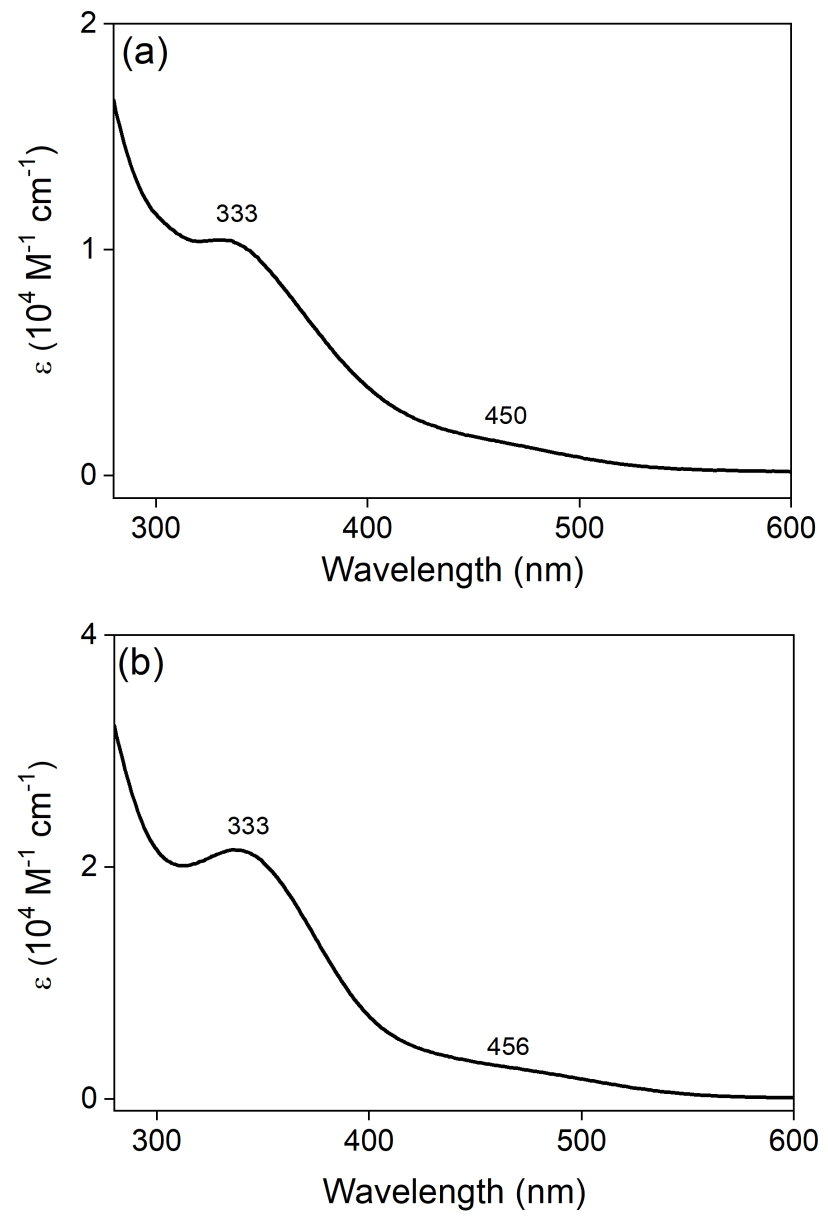

Figure S2. UV-vis spectra of $\mathbf{1}$ (a) and $\mathbf{2}$ (b) in $\mathrm{MeCN}$ solution. 

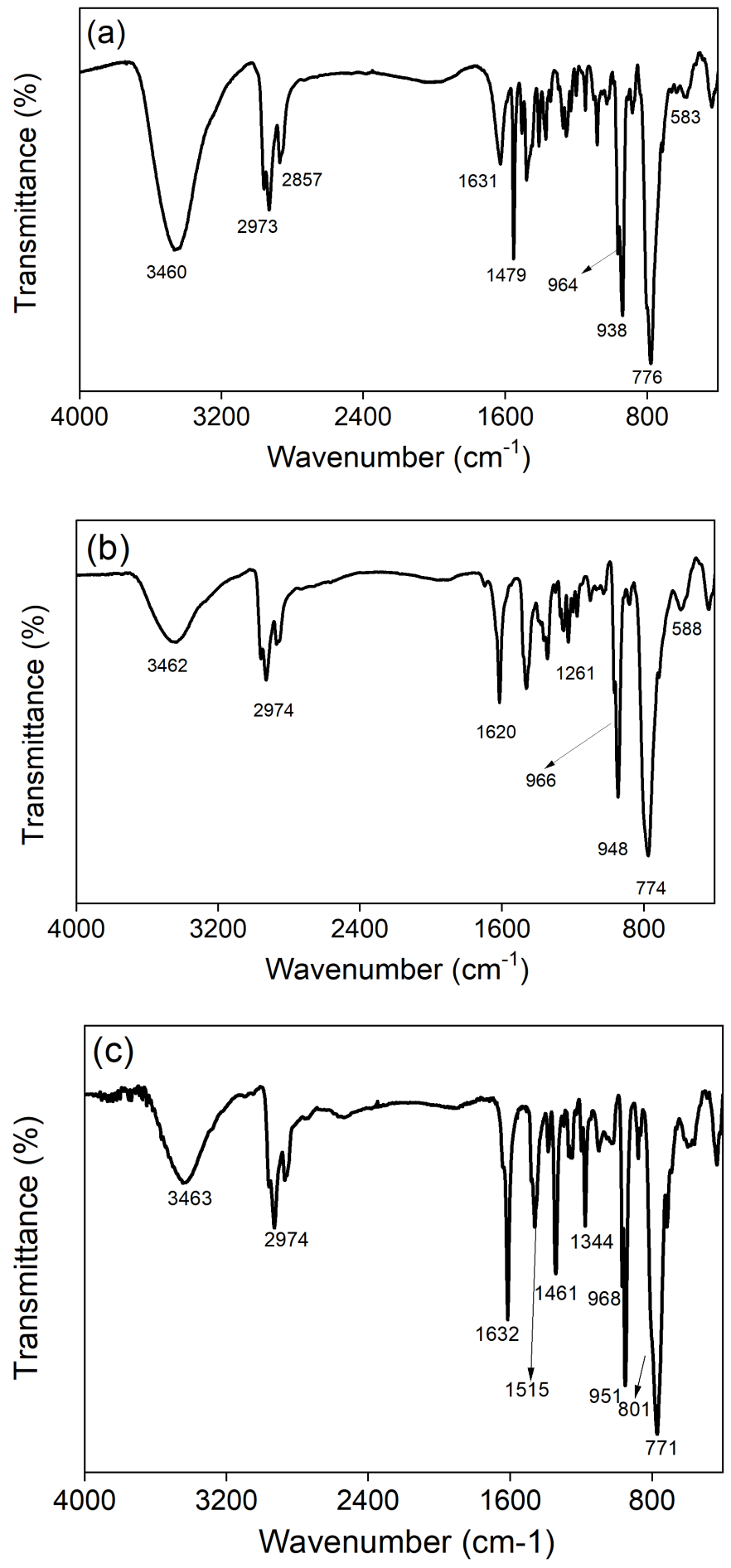

Figure S3. FTIR spectra of $\mathbf{1}$ (a), 2 (b) and $\mathbf{3}$ (c) in KBr pellets. 


\section{Thermal stability of the RN-POMs}

The RN-POMs remain stable in the process of the electrode preparation. Thermal degradation of RN-POMs 1-3 was investigated by thermogravimetric analysis (TGA). The thermal behavior of 1-3 in the lower temperature region is a 2-step gradual process (Figure S4). The weight loss of $\sim 1 \%$ in $30-120^{\circ} \mathrm{C}$ accounts for the loss of solvent molecules. Dissociation of the organic components including the aminopyridyl and related derivatives as well as the cyclohexyl groups is occurred at higher temperatures up to around 270,240 and $260{ }^{\circ} \mathrm{C}$ for $\mathbf{1 - 3}$, respectively, with the observed weight loss of $19.2 \%$ (ca. $20.2 \%$ ), $14.6 \%$ (ca. $15.4 \%$ ) and $16.4 \%$ (ca. $16.3 \%$ ), respectively. The thermal decomposition of $[\mathrm{TBA}]^{+}$cations accounts for the descending process in $350-500{ }^{\circ} \mathrm{C}$. The similar counter-ion degradation process is also observed for $[\mathrm{TBA}]_{2}\left[\mathrm{Mo}_{6} \mathrm{O}_{19}\right]$ in which the species remains stable up to $330{ }^{\circ} \mathrm{C}$ and the loss of the $[\mathrm{TBA}]^{+}(35.1 \%$, ca. $35.2 \%)$ occurs in the narrow temperature region of $330-450{ }^{\circ} \mathrm{C}$. Starting $450{ }^{\circ} \mathrm{C}$, the $\left\{\mathrm{Mo}_{6} \mathrm{O}_{19-\mathrm{x}}\right\}$ fragments of all samples are decomposed to metal-oxide greenish-black residues. According to the TGA results, it is concluded that all complexes remain intact in the fabrication process to coin cells for the capacity measurements.

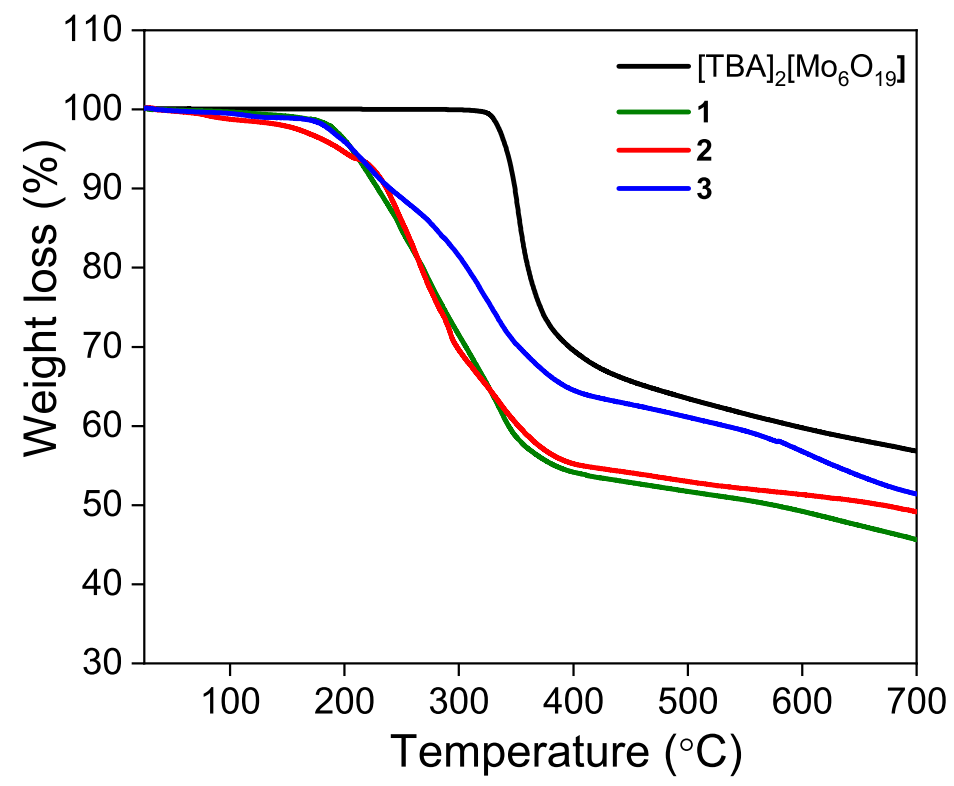

Figure S4. TGA plots of 1-3 and $[\mathrm{TBA}]_{2}\left[\mathrm{Mo}_{6} \mathrm{O}_{19}\right]$. 


\section{Surface areas and porosity of electrode materials fabricated with 3 and $[\mathrm{TBA}]_{2}\left[\mathrm{Mog}_{6} \mathrm{O}_{19}\right]$}

The $\mathrm{N}_{2}$ adsorption-desorption isotherms of both types of electrode materials indicate a type IV isotherm, suggesting a mixture of micro- and meso-porous materials. The isotherms at low pressures exhibit negligible uptake, corresponding to adsorption in micropores. The isotherms at high pressures $\left(>0.9 \mathrm{P} / \mathrm{P}_{0}\right)$ are of hysteresis loops, which are indicative of dislocation of non-rigid aggregates of POM clusters-CB particles during the adsorption-desorption isothermal processes.

Higher surface areas and larger pore volumes of electrode materials fabricated with $\mathbf{3}$ suggest that deposition of the RN-POM clusters with larger steric hindrance onto CB is able to better enhance the interfacial contact with the electrolytes and increase the accumulation of $\mathrm{Li}^{+}$ ions.
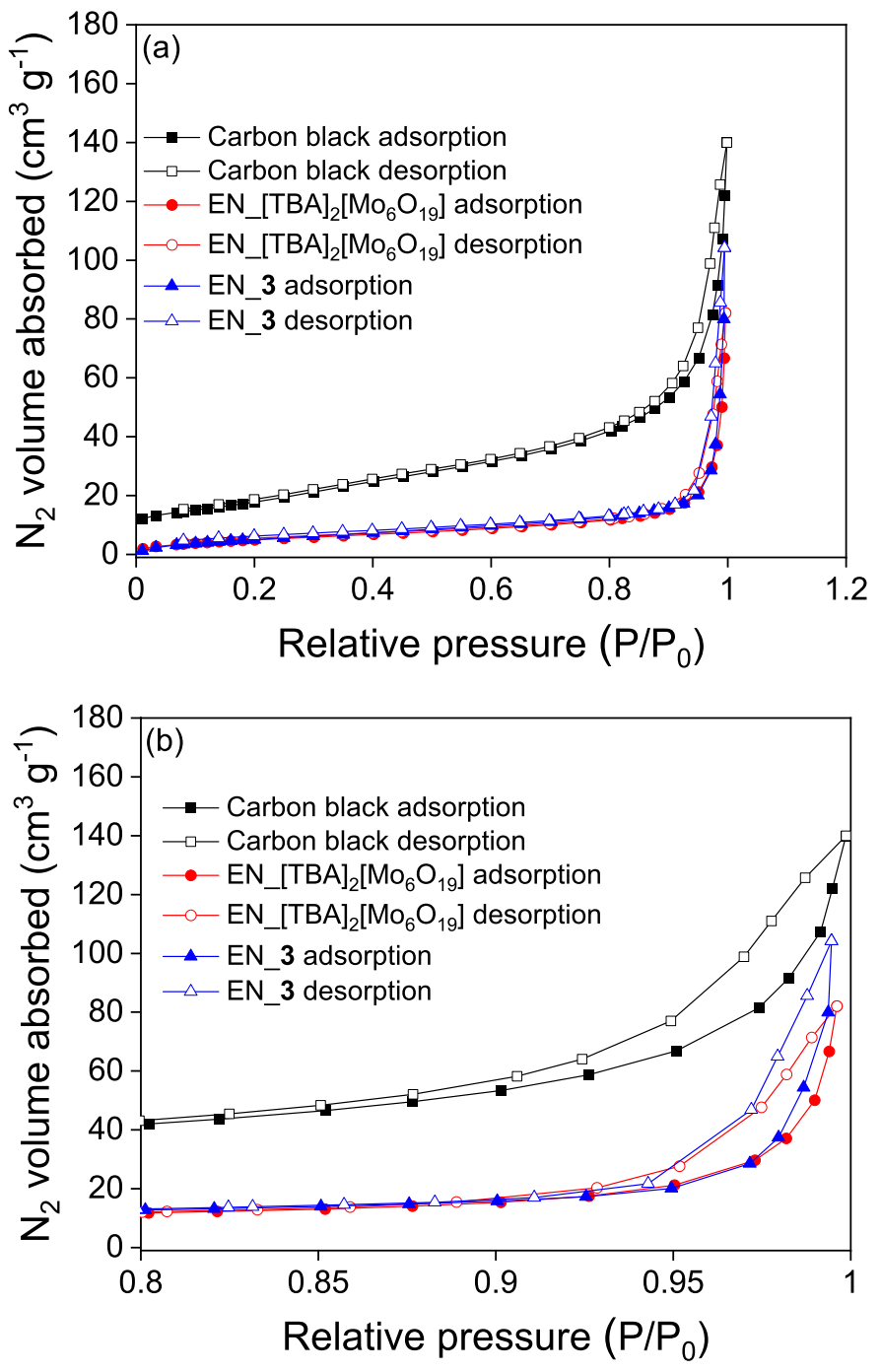

Figure S5. (a) $\mathrm{N}_{2}$ adsorption-desorption isotherms of $\mathrm{CB}$ and electrode materials. (b) The isotherms at high pressures display the hysteresis behavior. 


\section{Investigations of capacity performance}

$\underline{\text { The }} 1^{\text {st }}$ and $2^{\text {nd }}$ charge-discharge cycles
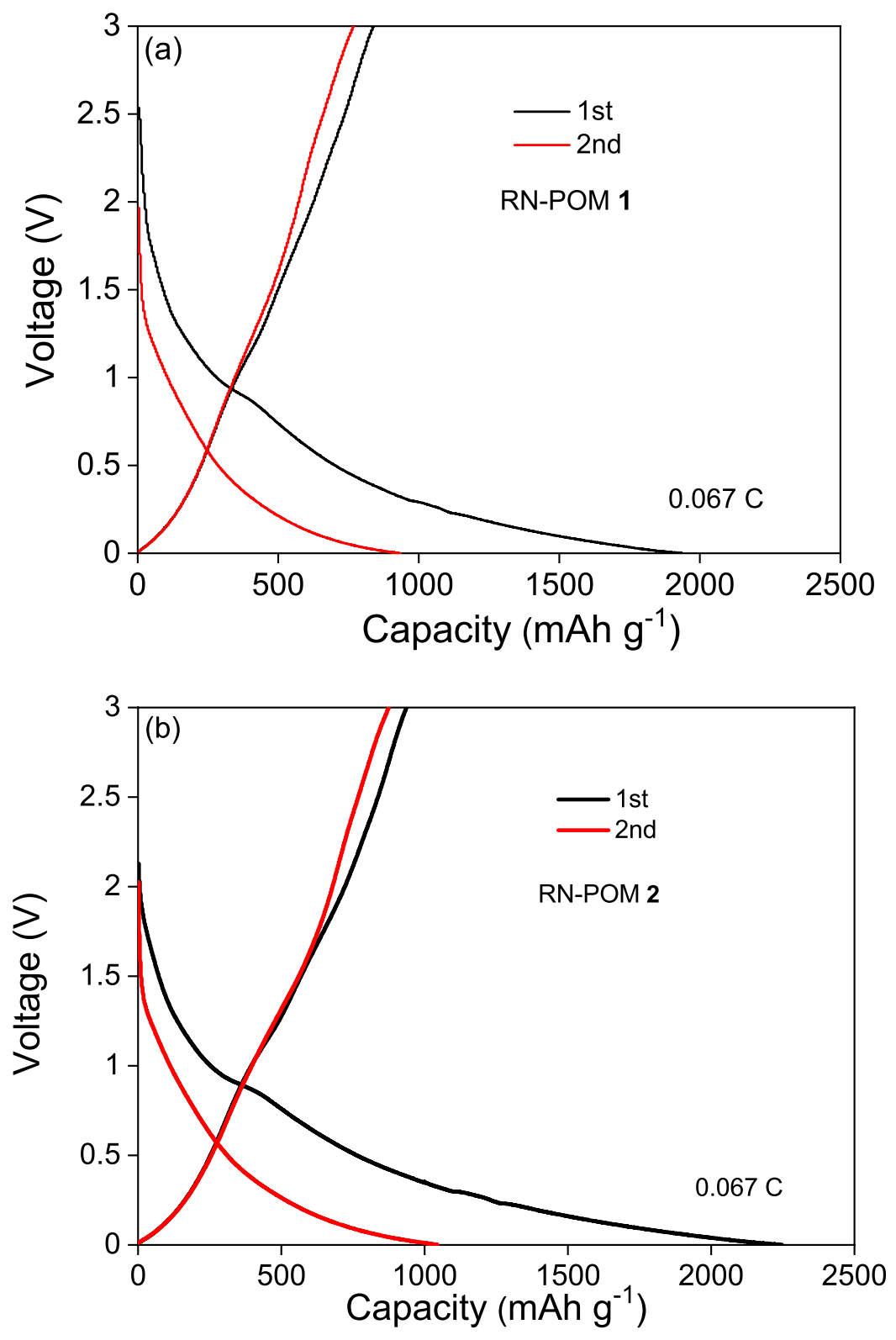


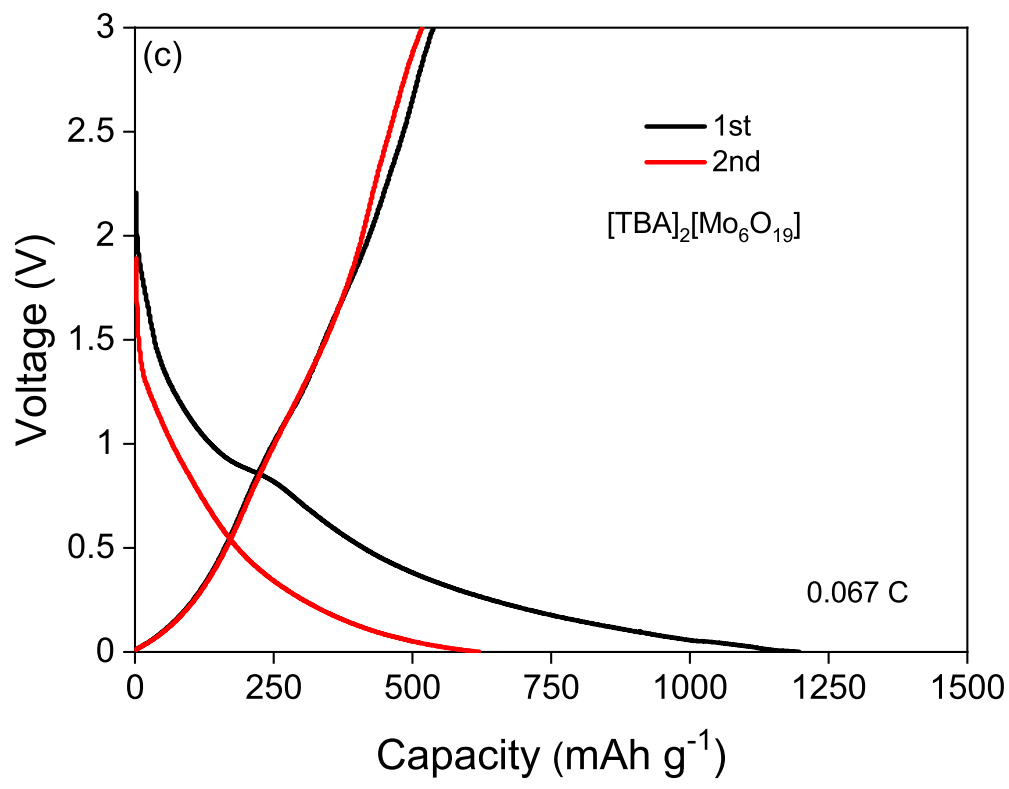

Figure S6. The $1^{\text {st }}$ and $2^{\text {nd }}$ charge-discharge cycle of $\mathbf{1}(\mathrm{a}), \mathbf{2}(\mathrm{b})$ and $[\mathrm{TBA}]_{2}\left[\mathrm{Mo}_{6} \mathrm{O}_{19}\right]$ (c).

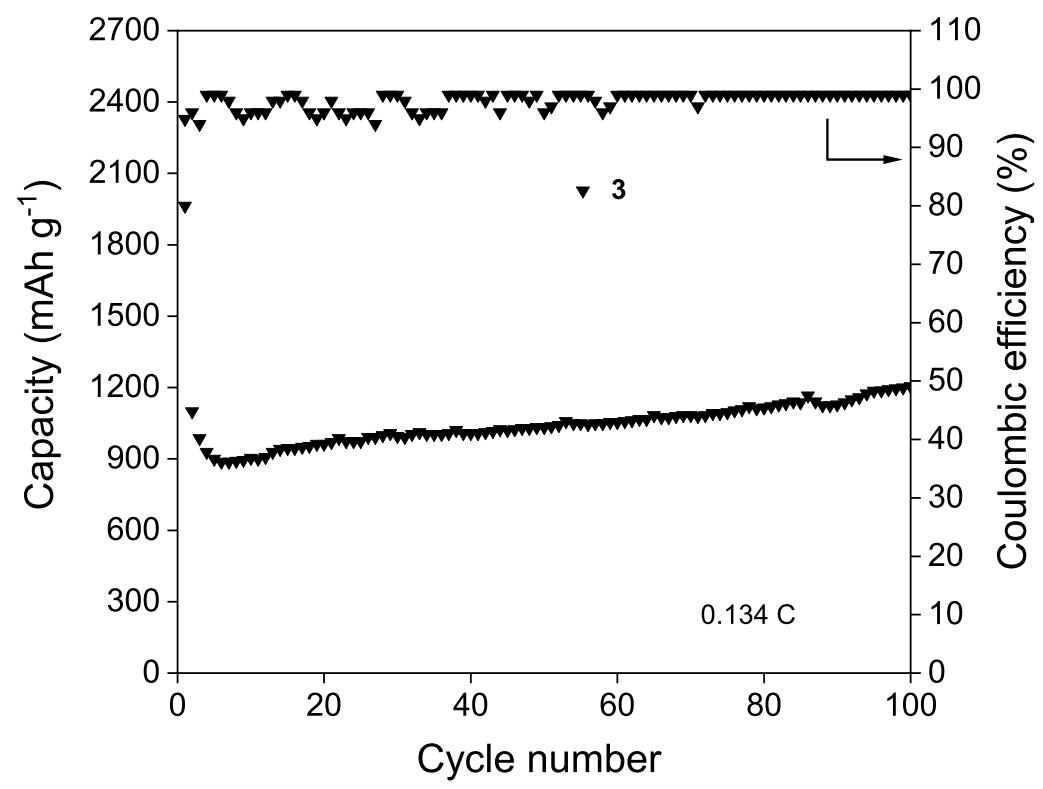

Figure S7. Cycle performance of 3 at $0.134 \mathrm{C}$. 


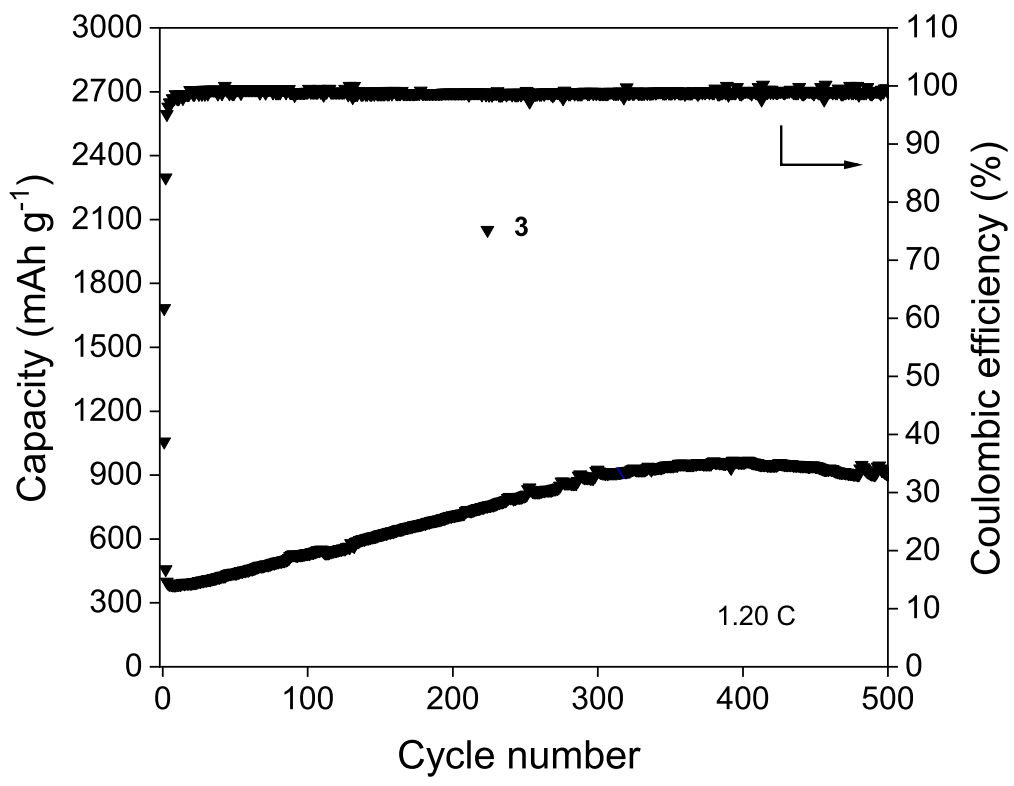

Figure S8. Cycle performance of $\mathbf{3}$ at $1.20 \mathrm{C}$.

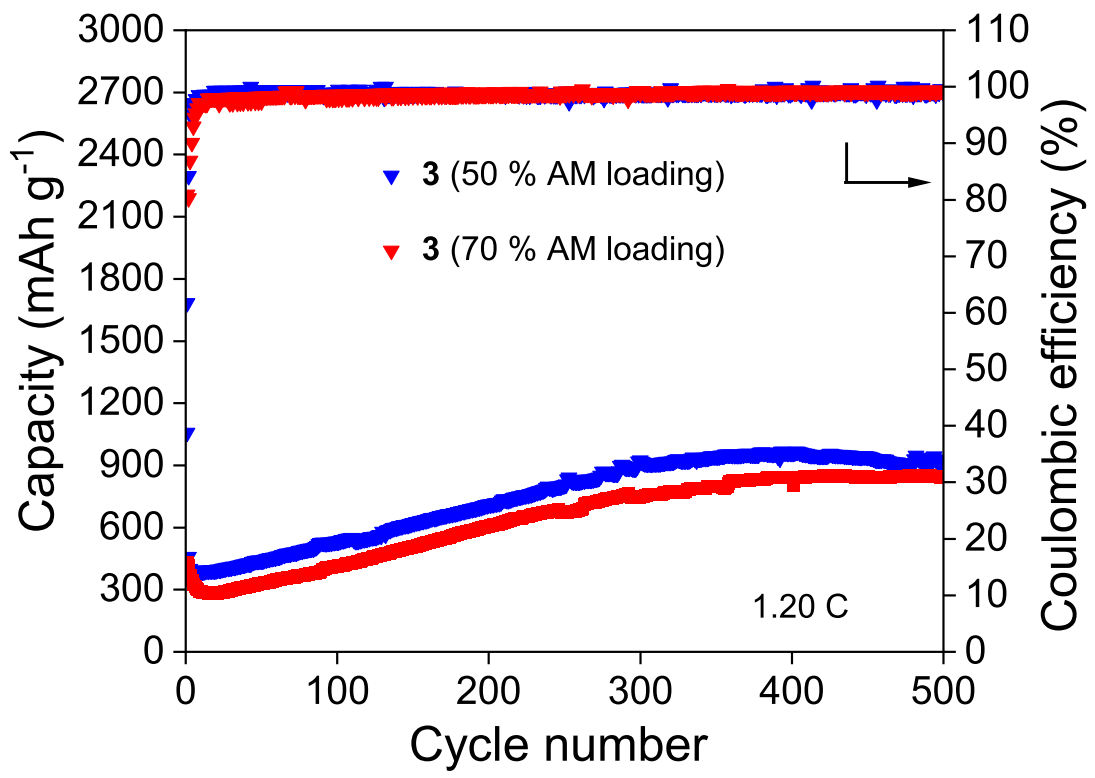

Figure S9. Cycle performance of 3 in a weight ratio of 70:20:10 (AM:CB:PVDF binder, red inverted triangles) and 50:40:10 (blue inverted triangles) at 1.20 C. 


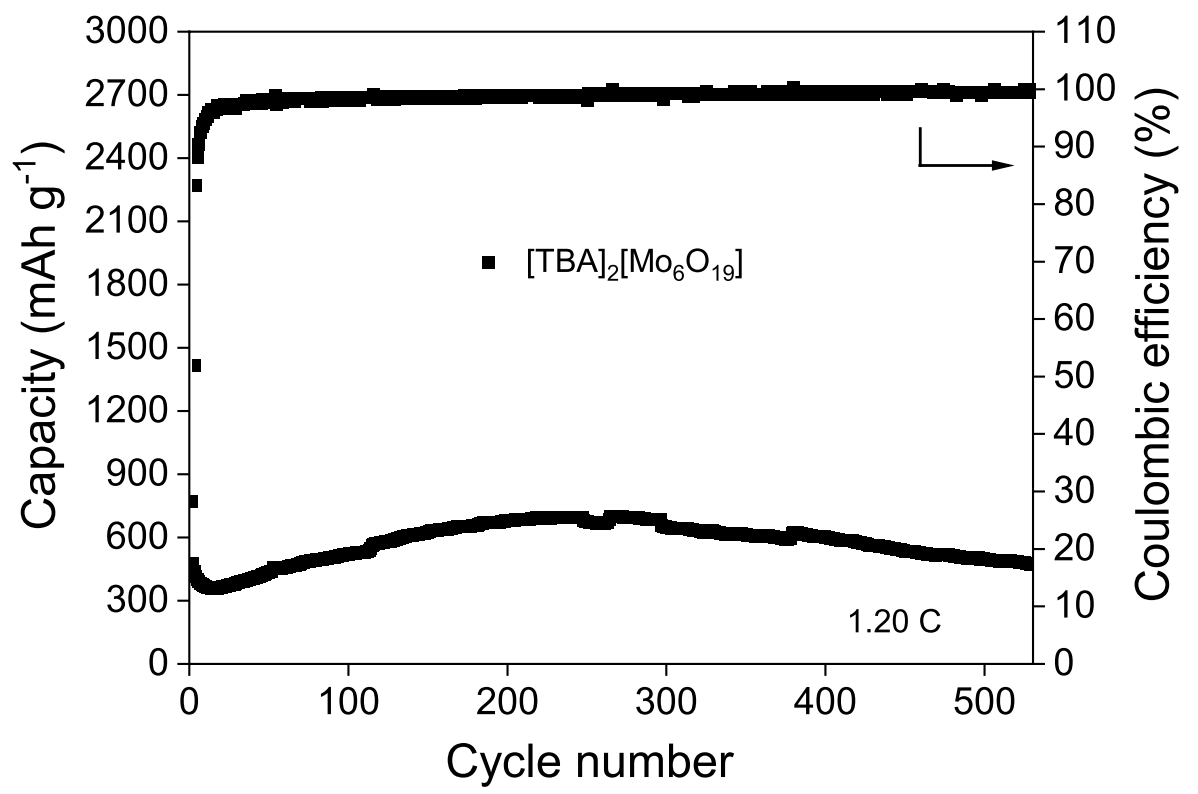

Figure S10. Cycle performance of $\left[\mathrm{TBA}_{2}\left[\mathrm{Mo}_{6} \mathrm{O}_{19}\right]\right.$ at $1.20 \mathrm{C}$.
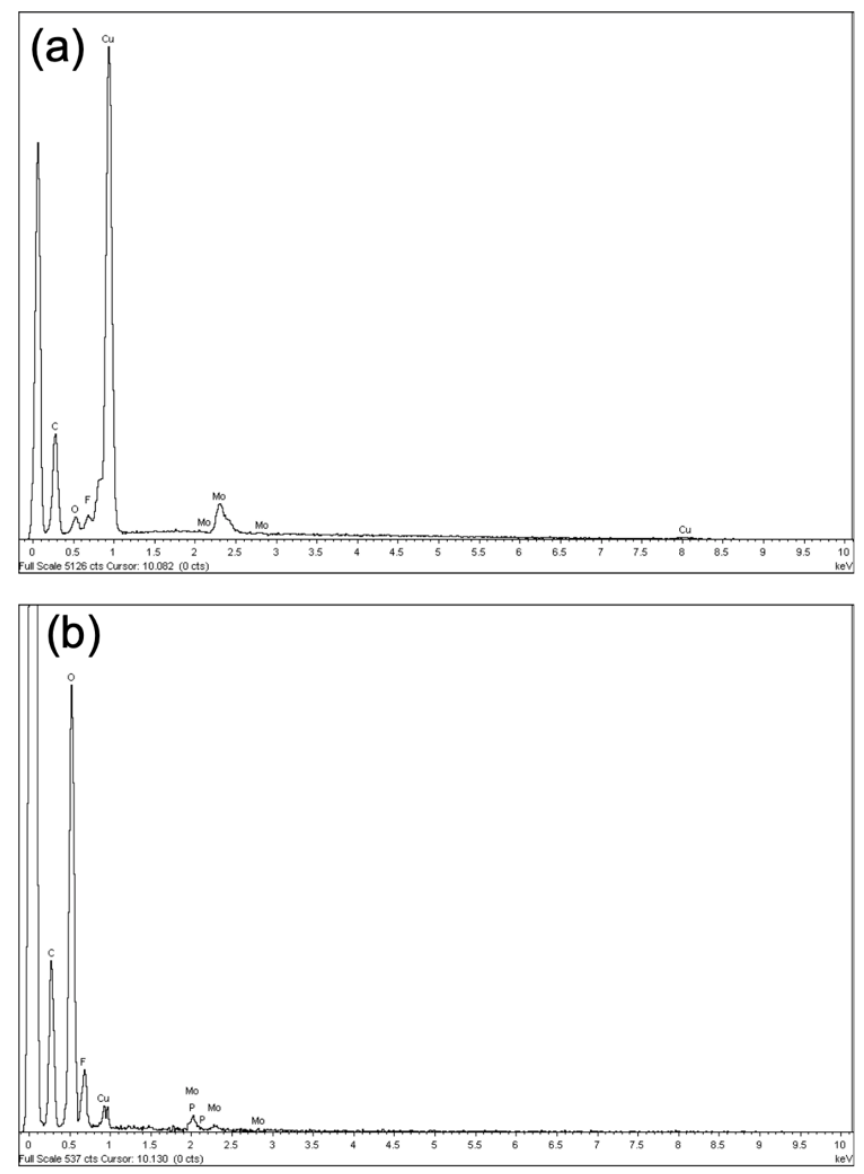

Figure S11. The EDX analysis of the F-electrode (a) and the top coating layer of the C-electrode (b). 

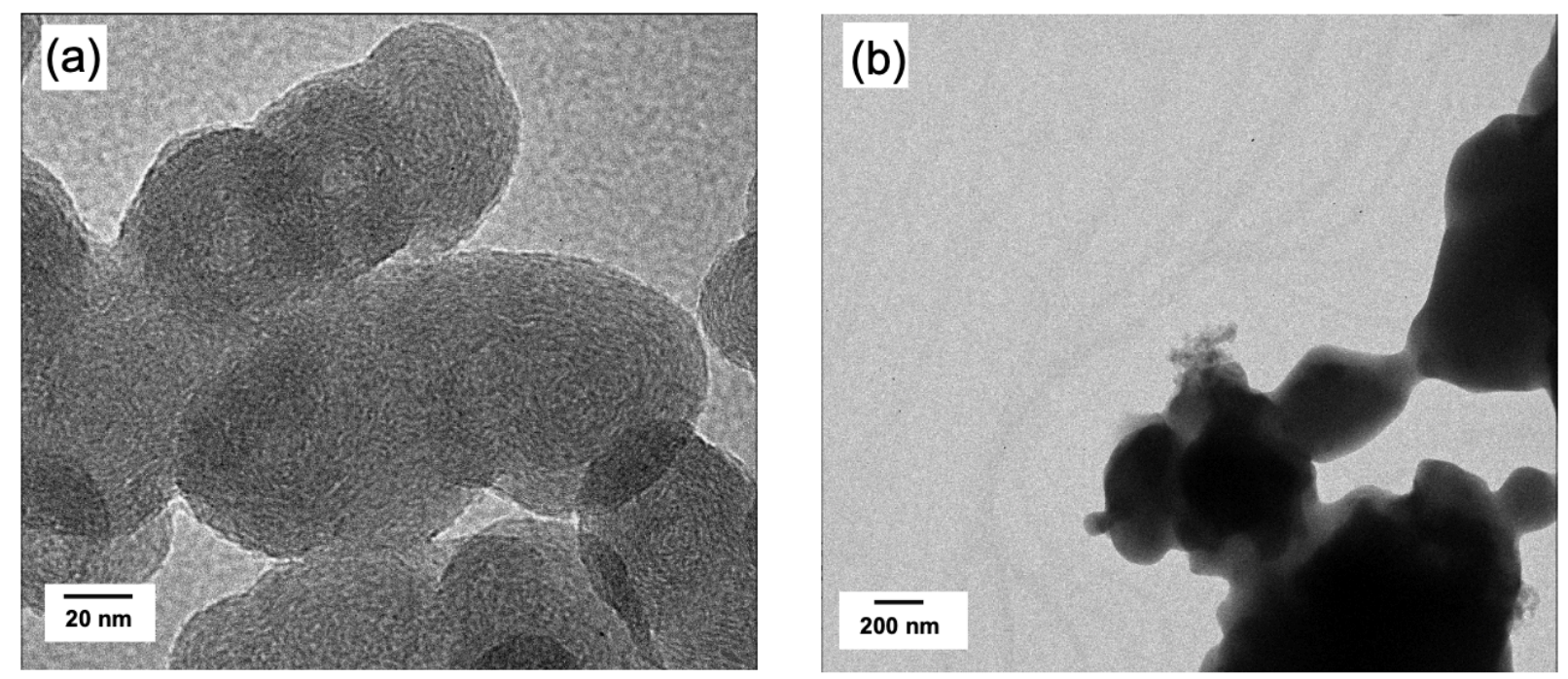

Figure S12. The TEM images of carbon black (a) and POM 3 (b).
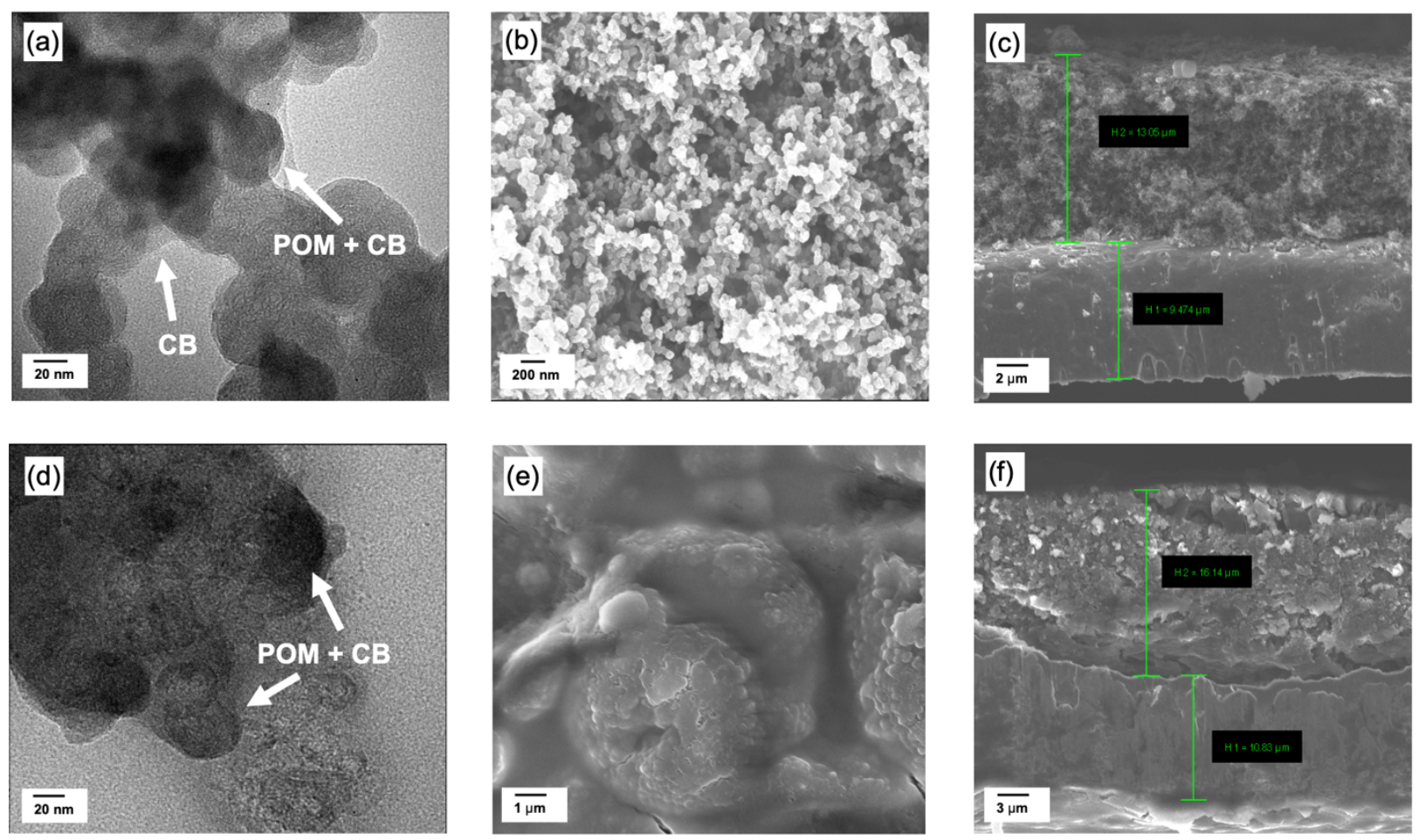

Figure S13. The TEM images of the electrode materials of $[\mathrm{TBA}]_{2}\left[\mathrm{Mo}_{6} \mathrm{O}_{19}\right]$ in the freshly prepared form (a) and after the 500 cycles of the charge-discharge process (d). Darker particles indicate the $\mathrm{Mo}_{6}$ clusters. The CB portion becomes darker, suggesting the distribution of the POM clusters over the $\mathrm{CB}$ materials. The SEM images of the electrode materials of $[\mathrm{TBA}]_{2}\left[\mathrm{Mo}_{6} \mathrm{O}_{19}\right]$ in the freshly prepared form (b; c, cross-section) and after the 500 cycles of the charge-discharge process (e; f, cross-section). 

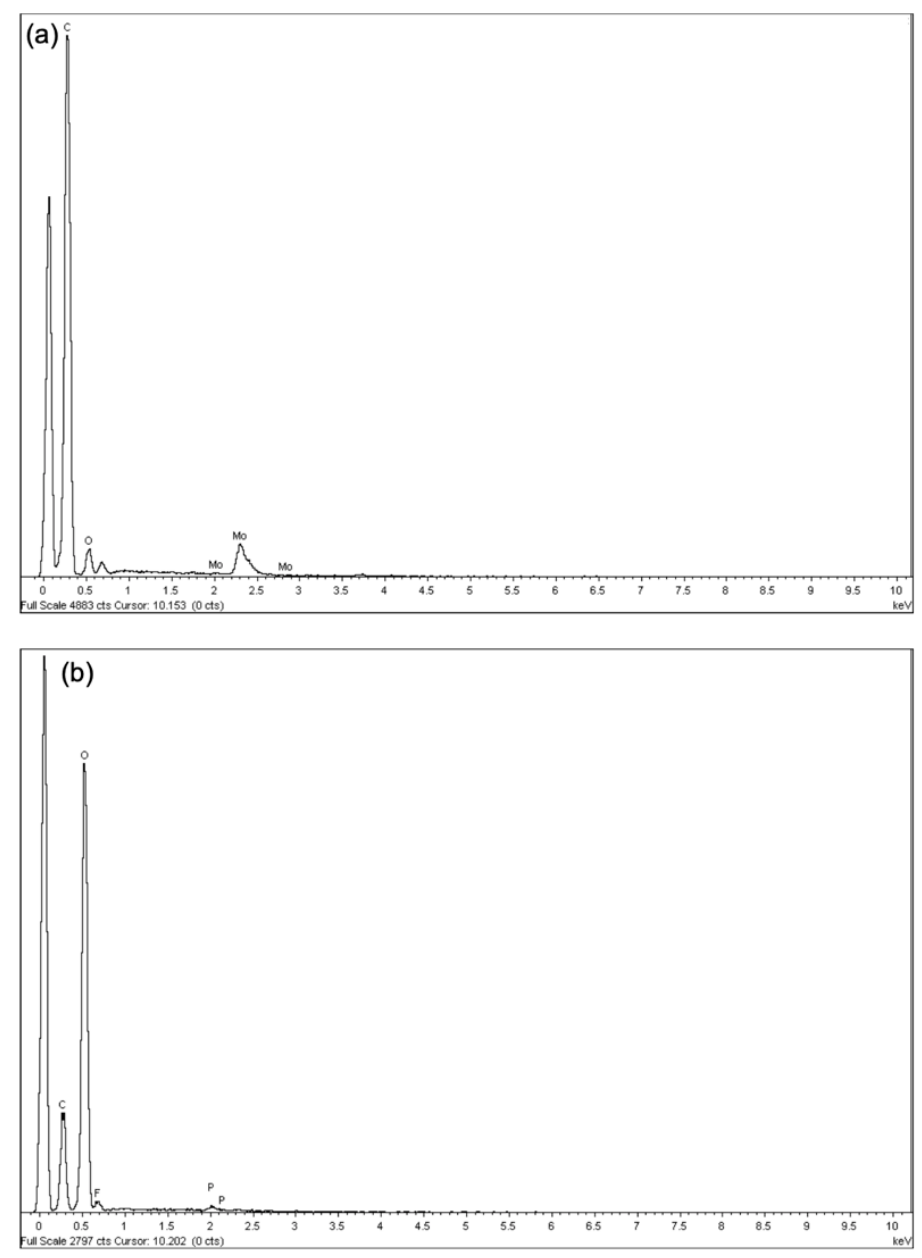

Figure S14. The EDX analysis of the electrode materials of $[\mathrm{TBA}]_{2}\left[\mathrm{Mo}_{6} \mathrm{O}_{19}\right]$ (fresh, a) and the top coating layer of the electrode materials of $[\mathrm{TBA}]_{2}\left[\mathrm{Mo}_{6} \mathrm{O}_{19}\right](500$ cycles, $b)$.

\section{Investigation of stability of the plateaued EM_3}

The cycled EM_3 remains stable according to the results of FTIR spectra. The coin cell comprised of EM_3 after 600 charge-discharge cycles was dismantled in dry box. The anode was removed from the coin cell, and washed by the following steps: dipped in THF solution for 2-3 times and gently rinsed with THF. Next, the anode was rinsed with hexane and left on a glass plate to dryness. The dried electrode material scratched from the copper foil was ground with $\mathrm{KBr}$, and pressed to pellets for the FTIR measurements. The IR profile of the cycled EM_3 is similar to that of the fresh one while shifted to lower wavenumber by $\sim 100 \mathrm{~cm}^{-1}$ (Figure S15). The $v\left(\mathrm{Mo}^{\mathrm{N}}-\mathrm{N}_{\mathrm{t}}\right)$ 
and $v\left(\mathrm{Mo}-\mathrm{O}_{\mathrm{t}}\right)$ for the cycled and fresh EM_3 are 865, $835 \mathrm{~cm}^{-1}$, and 963, $942 \mathrm{~cm}^{-1}$, respectively. The vibrational band of the Mo- $\mathrm{O}_{\mathrm{b}}$ is 672 and $775 \mathrm{~cm}^{-1}$, respectively. The results suggest that RNPOM 3 in the cycled EM_3 is in the reduced state, and the POM structure remains intact.

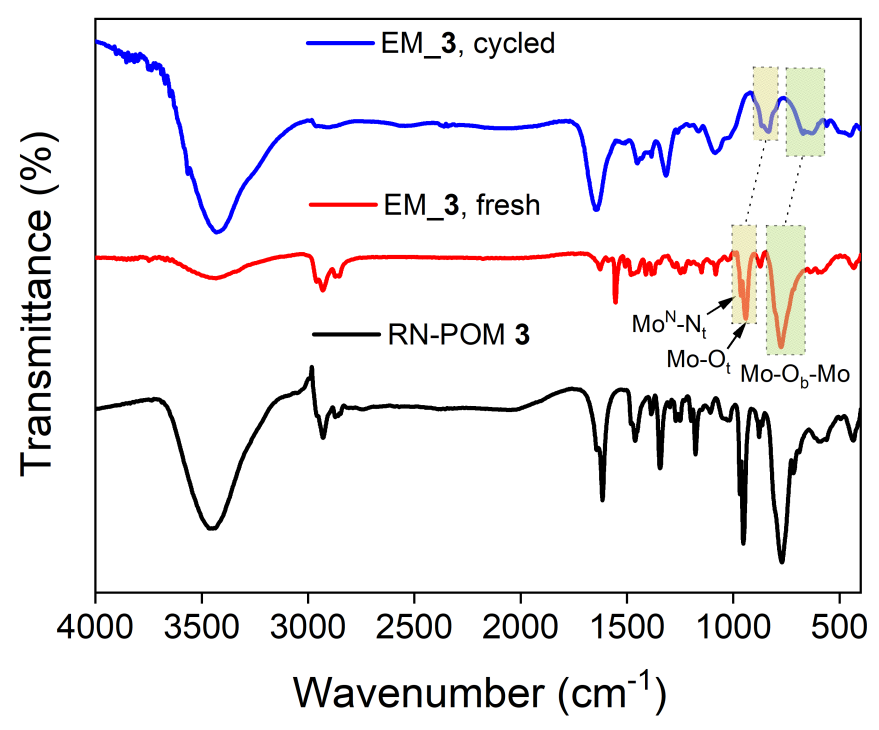

Figure S15. Comparison of FTIR spectra of RN-POM 3, the fresh EM_3 and the cycled EM_3 in $\mathrm{KBr}$ pellets.

\section{Calculation of diffusion coefficient $\left(D_{\mathrm{Li}}\right)$ of $\mathrm{Li}^{+}$ions}

The lithium-ion diffusivity parameter $\left(D_{\mathrm{Li}+}\right)$ is calculated according to the following equation. ${ }^{20}$

$$
D_{\mathrm{Li+}}=\frac{R^{2} T^{2}}{2 A^{2} n^{4} F^{4} C_{0}^{2} \sigma^{2}}
$$

where $R$ is the gas constant, $T$ is the temperature in Kelvin, $A$ is the surface area of the electrode, $n$ is the number of moles of electrons transferred in the redox process, $F$ is the Faraday constant; $C_{0}$ is the initial $\mathrm{Li}^{+}$concentration, $\sigma$ is the Warburg factor, obtained from the slope of the following equation.

$$
Z^{\prime}=R_{\mathrm{s}}+R_{\mathrm{ct}}+\sigma \omega^{-1 / 2}
$$

where $\omega$ is the angular frequency. From the linear relationship between $Z$ ' and $\omega^{-1 / 2}$, we are able to yield the value of the $\sigma$ parameter (Figure S15). The corresponding $D_{\mathrm{Li}}+$ values are consequently calculated. The results are summarized in Table S4. 


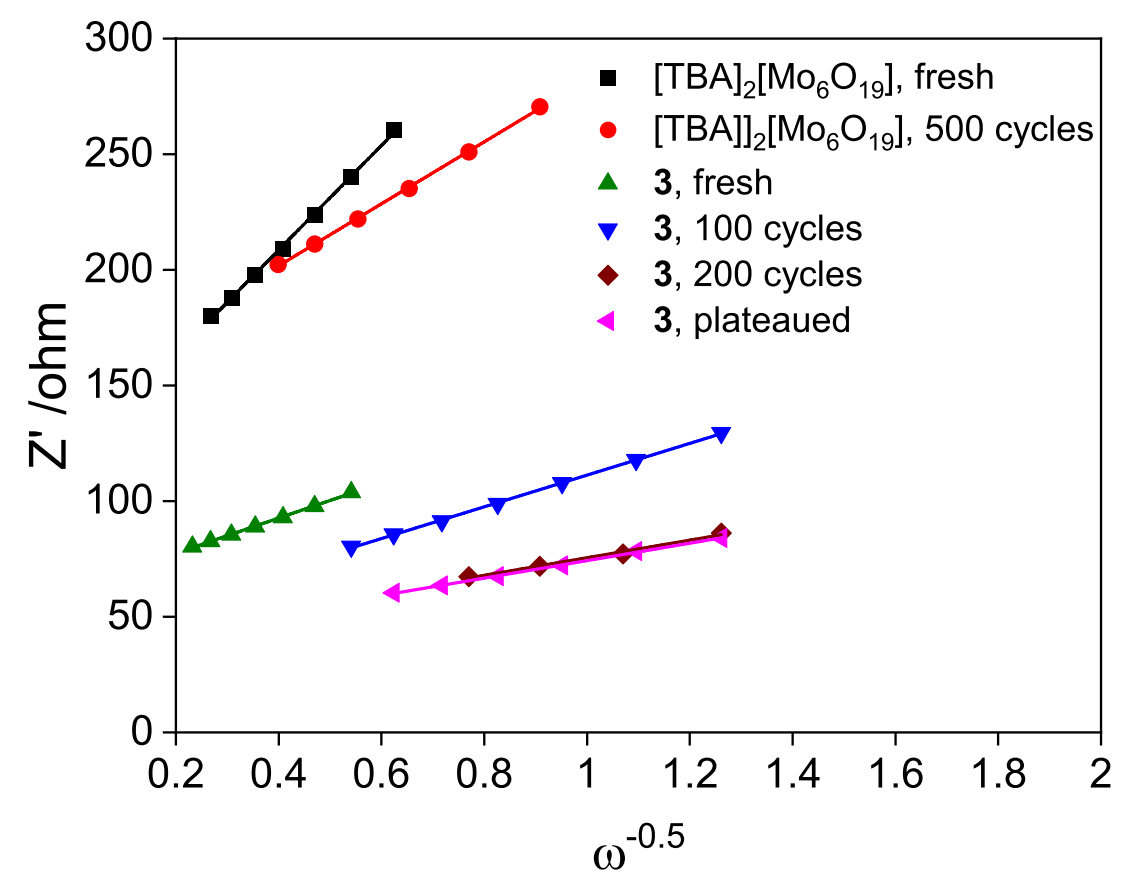

Figure S16. The linear relationship between $Z^{\prime}$ and $\omega^{-1 / 2}$ of $\mathbf{3}$ (fresh, $\mathrm{R}^{2}=0.9983 ; 100$ cycles, $\mathrm{R}^{2}$ $=0.9992 ; 200$ cycles, $\mathrm{R}^{2}=0.9878$; plateaued, $\left.\mathrm{R}^{2}=0.9988\right)$ and $[\mathrm{TBA}]_{2}\left[\mathrm{Mo}_{6} \mathrm{O}_{19}\right]$ (fresh, $\mathrm{R}^{2}=$ $0.9979 ; 500$ cycles, $\left.\mathrm{R}^{2}=0.9994\right)$ at the low frequency region.

Table S4. Simulated Warburg factor $(\sigma)$ and calculated lithium-ion diffusivity parameter $\left(D_{\mathrm{Li}+}\right)$ for 3 (fresh, 100 cycles, 200 cycles, and plateaued) and [TBA $]_{2}\left[\mathrm{Mo}_{6} \mathrm{O}_{19}\right]$ (fresh, and 500 cycles).

\begin{tabular}{|c|c|c|}
\hline complex & $\sigma\left(\Omega \mathrm{cm}^{2} \mathrm{~s}^{-1 / 2}\right)$ & $D_{\mathrm{Li}}\left(\mathrm{cm}^{2} \mathrm{~s}^{-1}\right)$ \\
\hline 3, fresh & 76.14 & $3.33 \times 10^{-12}$ \\
\hline $\mathbf{3}, 100$ cycles & 68.60 & $4.11 \times 10^{-12}$ \\
\hline $\mathbf{3}, 200$ cycles & 38.04 & $1.34 \times 10^{-11}$ \\
\hline $\mathbf{3}$, plateaued & 37.68 & $1.36 \times 10^{-11}$ \\
\hline$[\mathrm{TBA}]_{2}\left[\mathrm{Mo}_{6} \mathrm{O}_{19}\right]$, fresh & 226.0 & $3.78 \times 10^{-13}$ \\
\hline$[\mathrm{TBA}]_{2}\left[\mathrm{Mo}_{6} \mathrm{O}_{19}\right], 500$ cycles & 133.9 & $1.08 \times 10^{-12}$ \\
\hline
\end{tabular}




\section{References}

1. Nasim Khan, R. N.; Mahmood, N.; Lv, C.; Sima, G.; Zhang, J.; Hao, J.; Hou, Y.; Wei, Y., Pristine organo-imido polyoxometalates as an anode for lithium ion batteries. $R S C A d v . \mathbf{2 0 1 4}, 4$ (15), 7374-7379.

2. $\quad$ Zhang, A. M.; Zhang, M.; Lan, D.; Wang, H.-N.; Tang, Y.-J.; Wang, X.-L.; Dong, L.-Z.; Zhang, L.; Li, S.-L.; Lan, Y.-Q., Polyoxometalate-Based Metal-Organic Framework on Carbon Cloth with a Hot-Pressing Method for High-Performance Lithium-Ion Batteries. Inorg. Chem. 2018, 57 (18), 11726-11731.

3. Chen, X.; Wang, Z.; Zhang, R.; Xu, L.; Sun, D., A novel polyoxometalate-based hybrid containing a 2D [CoMo8O26] $\infty$ structure as the anode for lithium-ion batteries. Chem. Commun. 2017, 53 (76), 10560-10563.

4. $\quad$ Wei, T.; Zhang, M.; Wu, P.; Tang, Y.-J.; Li, S.-L.; Shen, F.-C.; Wang, X.-L.; Zhou, X.-P.; Lan, Y.-Q., POM-based metal-organic framework/reduced graphene oxide nanocomposites with hybrid behavior of battery-supercapacitor for superior lithium storage. Nano Energy 2017, 34, 205-214.

5. Zhao, X.; Niu, G.; Yang, H.; Ma, J.; Sun, M.; Xu, M.; Xiong, W.; Yang, T.; Chen, L.; Wang, C., MIL-88A@polyoxometalate microrods as an advanced anode for high-performance lithium ion batteries. CrystEngComm 2020, 22 (21), 3588-3597.

6. Cheng, W.; Shen, F.-C.; Xue, Y.-s.; Luo, X.; Fang, M.; Lan, Y.-Q.; Xu, Y., A Pair of Rare Three-Dimensional Chiral Polyoxometalate-Based Metal-Organic Framework Enantiomers Featuring Superior Performance as the Anode of Lithium-Ion Battery. ACS Appl. Energy Mater. 2018, 1 (9), 4931-4938.

7. Hu, J.; Jia, F.; Song, Y.-F., Engineering high-performance polyoxometalate/PANI/MWNTs nanocomposite anode materials for lithium ion batteries. Chem. Eng. J. 2017, 326, 273-280.

8. Xie, J.; Zhang, Y.; Han, Y.; Li, C., High-Capacity Molecular Scale Conversion Anode Enabled by Hybridizing Cluster-Type Framework of High Loading with Amino-Functionalized Graphene. ACS Nano 2016, 10 (5), 5304-5313.

9. Jia, X.; Wang, J.; Hu, H.; Song, Y.-F., Three-Dimensional Carbon Framework Anchored Polyoxometalate as a High-Performance Anode for Lithium-Ion Batteries. Chem.-Eur. J. 2020, 26 (23), 5257-5263.

10. Ji, Y.; Hu, J.; Huang, L.; Chen, W.; Streb, C.; Song, Y.-F., Covalent Attachment of Anderson-Type Polyoxometalates to Single-Walled Carbon Nanotubes Gives Enhanced Performance Electrodes for Lithium Ion Batteries. Chem.-Eur. J. 2015, 21 (17), 6469-6474.

11. Ding, Y.-H.; Peng, J.; Khan, S.-U.; Yuan, Y., A New Polyoxometalate (POM)-Based Composite: Fabrication through POM-Assisted Polymerization of Dopamine and Properties as Anode Materials for High-Performance Lithium-Ion Batteries. Chem.-Eur. J. 2017, 23 (43), 10338-10343.

12. Hu, J.; Ji, Y.; Chen, W.; Streb, C.; Song, Y.-F., "Wiring" redox-active polyoxometalates to carbon nanotubes using a sonication-driven periodic functionalization strategy. Energy Environ. Sci. 2016, 9 (3), 1095-1101.

13. Huang, Q.; Wei, T.; Zhang, M.; Dong, L.-Z.; Zhang, A. M.; Li, S.-L.; Liu, W.-J.; Liu, J.; Lan, Y.-Q., A highly stable polyoxometalate-based metal-organic framework with $\pi-\pi$ stacking for enhancing lithium ion battery performance. J. Mater. Chem. A 2017, 5 (18), 8477-8483. 
14. Shon, J. K.; Lee, H. S.; Park, G. O.; Yoon, J.; Park, E.; Park, G. S.; Kong, S. S.; Jin, M.; Choi, J.-M.; Chang, H.; Doo, S.; Kim, J. M.; Yoon, W.-S.; Pak, C.; Kim, H.; Stucky, G. D., Discovery of abnormal lithium-storage sites in molybdenum dioxide electrodes. Nat. Commun. 2016, 7 (1), 11049.

15. Bhaskar, A.; Deepa, M.; Narasinga Rao, T., MoO2/Multiwalled Carbon Nanotubes (MWCNT) Hybrid for Use as a Li-Ion Battery Anode. ACS Appl. Mater. Interfaces 2013, 5 (7), 2555-2566.

16. Tang, Q.; Shan, Z.; Wang, L.; Qin, X., MoO2-graphene nanocomposite as anode material for lithium-ion batteries. Electrochim. Acta 2012, 79, 148-153.

17. Huang, Z. X.; Wang, Y.; Zhu, Y. G.; Shi, Y.; Wong, J. I.; Yang, H. Y., 3D graphene supported $\mathrm{MoO} 2$ for high performance binder-free lithium ion battery. Nanoscale 2014, 6 (16), 9839-9845.

18. Patil, S. B.; Udayabhanu; Kishore, B.; Nagaraju, G.; Dupont, J., High capacity MoO3/rGO nanocomposite anode for lithium ion batteries: an intuition into the conversion mechanism of MoO3. New J. Chem. 2018, 42 (23), 18569-18577.

19. Zhang, H.-J.; Wu, T.-H.; Wang, K.-X.; Wu, X.-Y.; Chen, X.-T.; Jiang, Y.-M.; Wei, X.; Chen, J.-S., Uniform hierarchical $\mathrm{MoO} 2 /$ carbon spheres with high cycling performance for lithium ion batteries. J. Mater. Chem. A 2013, 1 (39), 12038-12043.

20. Ding, J.; Abbas, S. A.; Hanmandlu, C.; Lin, L.; Lai, C.-S.; Wang, P.-C.; Li, L.-J.; Chu, C.W.; Chang, C.-C., Facile synthesis of carbon/MoO3 nanocomposites as stable battery anodes. $J$. Power Sources 2017, 348, 270-280. 